\title{
MULTI LEVEL EDUCATION KATOGA IMPROVE THE COMPETENCE OF HEALTH CADRES, PUBLIC FIGURE, AND FAMILY IN PREVENTING, EARLY DETECTION AND HANDLING PREGNANCY EMERGENCY
}

\author{
Ratna Hidayati ${ }^{1}$, Dwi Setyorini ${ }^{2}$ \\ ${ }^{1,2}$ STIKES Karya Husada Kediri \\ Ratnahidayati1971@gmail.com
}

\begin{abstract}
Introduction: Extraordinary policies have been launched by the government to reduce Maternal Mortality Ratel Infant Mortality Rate (MMR/IMR), however this has not been comparable with the expected results. The purpose of this study was to determine the effectiveness of Katoga's multi-level education on the competence of cadres, public figure, and families in preventing, detecting early and handling emergency pregnancy to reduce MMR/IMR. Methods: This research study used action research with stratified respondents, 10 health cadres who will provide training to 30 community leader respondents and subsequently public figure will provide training to 60 selected families with simple random sampling. The independent variable was multi-level education and the dependent variable was competence in early detection of emergencies in pregnancy. Data were collected using a questionnaire and analyzed by t-test. Results: The results showed that the increasing of the competence in preventing, early detecting and handling emergency pregnancy after receiving multilevel education training in health cadres from the previous value of 70 to 93; in community leaders from 61.1 to 80.5 and in families from 58.0 to 78.9. There was a significant increase in competency with multi-level education training in increasing competency in a larger population with a cadre pValue of 0.003; community leaders 0,000 and families 0,000. Conclusions: Community empowerment in the health sector through multi-level education can spread knowledge in preventing, detecting high-risk pregnancies early and managing maternal emergencies so as to facilitate the task of health nurses to obtain information about pregnant women detected as high-risk populations.
\end{abstract}

Keywords: cadre-public figure-family competency; emergency pregnancy; multilevel education

\section{INTRODUCTION}

Maternal mortality rate (MMR) is an indicator of a country's health status. Said to be an indicator because the health status of all family members is inseparable from the role of a mother in handling the health of family members. If maternal health is disrupted, no one will provide food that supports family health at home, clean the house and its contents, the education of her children, and many other roles. Therefore the high maternal mortality rate is a bad incident for the health of other family members. In Indonesia AKI has not met the Millennium Development Goals (MDGs) target of 102/100,000 live births in 2015 (2012 IDHS data was 359/100,000). The decline in MMR that has not been as expected in Indonesia is different from the achievement in other poor and developing countries in other Asian countries (Sastrawinata, 2010). Entering the era of
Sustainable Development Goals (SDGs) need harder efforts to reduce MMR by the government through health service workers and health facilities as well as community participation (including universities, especially educational institutions printing health workers) (Acni, Nurul, and PKP, 2013) . One of the fundamental changes brought by the SDGs is the principle of "no one is left". This means that the range of targets and services in the era of SDGs is more comprehensive (100\%) compared to the era of the MDGs. Entering the era of Sustainable Development Goals (SDGs) need harder efforts to reduce MMR by the government through health service workers and health facilities as well as community participation (including universities, especially educational institutions printing health workers) (Acni, Nurul, and PKP, 2013). One of the fundamental changes brought by the SDGs is the principle of "no one is left". This means 
that the range of targets and services in the era of SDGs is more comprehensive (100\%) compared to the era of the MDGs.

An important problem in Indonesia, every hour one woman dies during childbirth due to causes related to pregnancy. The biggest causes of MMR are postpartum hemorrhage (28\%), preeclampsia (24\%), infection (11\%), labor complications (11\%), prolonged birth (5\%) and abortion (5\%). From various studies, it can be concluded that the causes of death are caused by the delay in making decisions, being late in traveling and being late getting treatment at health service facilities. (Syafiq and Budiantoro,2013).

The government's efforts in reducing the MMR / IMR has been started, through: 1) Safe motherhood with four pillars (KB, ANC, childbirth safe and comfortable, as well as essential obstetric services); 2) Mother's care; 3) Early Breastfeeding Initiation (IMD); 4) Expanding Maternal and Newborn Survival (EMAS); As well as other efforts aimed at ensuring maternal health and well-being so as to reduce MMR (Turniani and Roosihermiatie, 2007).

Considering the government's efforts to reduce the MMR have been so good but the results have not been as expected, then there is no harm in us looking at the countries around us who have succeeded in reducing the MMR. As we know, Sri Lanka has an MMR of $30 / 100,000$ live births and Thailand's AKI of 40 / 100,000 live births. The policies that they have been working on so that the MMR is so declining are using strategy techniques: 1) Family Planning Program, which using family planning will prevent a woman from getting pregnant, minimize and avoid complications in pregnancy / birth which ultimately prevent death due to childbirth;2) Improving utilization and quality of care which emphasizes on giving free life-saving care; 3) Expanding access to more effective maternity care by midwives and doctors (Week, 2007). There are also differences in the patterns of other countries in reducing the community are automatically
MMR, for example Sweden with the policy "adherence to use aseptic technique"; Japan with "proffessionalization of deliveries at home"; Malaysia with "growing the socioeconomic system, supporting the efforts of safe motherhood management policies and using the health care facility as well"; and North Europe with "well coordination among ANC-delivery-postpartum".

Actually, the above policy program has also been implemented in our country Indonesia (Joint Committee, 2013). But it hasn't succeeded as expected. There needs to be commitment and continuity as the key to success that so far these countries have done, namely: 1) Improving the role of professional personnel; 2) Giving accurate and continuous information; 3) Improving the professional skills to make them professional. For Giving points accurate and continuous information needs to be increased again to be effective in helping to reduce MMR. In addition we can also learn from the failure of developed countries in the United States in the past 70s that did not succeed in reducing the MMR. Because of the erroneous arrogance of health professionals, they always do not cooperate in all lines, so that the adverse effects of failing to reduce MMR (Macdorman et al., 2016). For this reason, it is necessary to involve all components of the community from cadres, community leaders to families to care in the efforts of early detection and management of maternal emergencies. Through multi-level learning methods, Katoga educators (community-family leaders) are expected to be able to increase the community's ability to detect early and manage maternal emergencies, so as to reduce MMR and also indirectly reduce IMR. This is because of our effectiveness as health workers in providing education to the community because of the multilevel education system. We only provide education to a few people, so the tasks we give will be disseminated so that not many members of

covered. The purpose of this study was to 
study the effectiveness of Katoga's (familypublic figure-community) multi-level learning methods of resistance, early detection and emergency pregnancy management to increase MMR/IMR.

\section{METHODS}

The design of this research is action research with a tiered research sample of 10 health cadres selected by cluster sampling, the next stage the cadre respondents choose 30 public figure as the next research subject and continue to the community place, choosing 60 families as further research subjects. The variables of this study are the knowledge and skills of health cadres about the prevention, early detection and handling of emergency pregnancy. The instrument used was a questionnaire. Data analysis using a t-test computer program. This study has received ethical approval from the Health Research Ethics Commission of STIKES Karya Husada
Kediri no.

STIKES/KH/07/2019.

116/EC/LPPM/

\section{RESULTS}

Characteristics of respondents based on age in health cadres are 34-37 years as much as $60 \%$, in public figures aged $42-45$ years as much as $60 \%$ and families aged $34-37$ years as much as $41.6 \%$. Characteristics of respondents based on education in health cadres are high school as much as $60 \%$, in public figures education Elementary / middle school as much as $60 \%$, and families education Elementary / middle school as much as $41.6 \%$. While the characteristics of respondents based on work in the health cadre are as much as $100 \%$ of housewife, in the public figures of Entrepreneur $\&$ Civil servants as much as $60 \%$, and housewife families as much as $43.5 \%$.

Tabel 1. Distribution of Respondent Characteristik

\begin{tabular}{|c|c|c|c|c|c|c|}
\hline \multirow[t]{2}{*}{ Age/Respondents } & \multicolumn{2}{|c|}{ Health Cadre } & \multicolumn{2}{|c|}{ Public Figures } & \multicolumn{2}{|c|}{ Families } \\
\hline & $\mathrm{n}$ & $\%$ & $\mathrm{n}$ & $\%$ & $\mathrm{n}$ & $\%$ \\
\hline $34-37$ & 6 & 60 & 6 & 20 & 25 & 41,6 \\
\hline $38-41$ & 2 & 20 & 6 & 20 & 22 & 36,7 \\
\hline $42-45$ & 2 & 20 & 18 & 60 & 13 & 21,7 \\
\hline Total & 10 & 100 & 30 & 100 & 60 & 100 \\
\hline \multirow[t]{2}{*}{ Education/ Respondents } & \multicolumn{2}{|c|}{ Health Cadre } & \multicolumn{2}{|c|}{ Public Figures } & \multicolumn{2}{|c|}{ Families } \\
\hline & $\mathbf{n}$ & $\%$ & $\mathbf{n}$ & $\%$ & $\mathbf{n}$ & $\%$ \\
\hline Elementary/middle school & 2 & 20 & 18 & 60 & 25 & 41,6 \\
\hline High School & 6 & 60 & 6 & 20 & 22 & 36,7 \\
\hline Diploma / Bachelor Degree & 2 & 20 & 6 & 20 & 13 & 21,7 \\
\hline Total & 10 & 100 & 30 & 100 & 60 & 100 \\
\hline \multirow[t]{2}{*}{ Occupation /Respondents } & \multicolumn{2}{|c|}{ Health Cadre } & \multicolumn{2}{|c|}{ Public Figures } & \multicolumn{2}{|c|}{ Families } \\
\hline & $\mathbf{n}$ & $\%$ & $\mathbf{n}$ & $\%$ & $\mathbf{n}$ & $\%$ \\
\hline Housewife & 10 & 100 & 5 & 16,7 & 26 & 43,3 \\
\hline Private & 0 & 0 & 7 & 23,3 & 15 & 25 \\
\hline Entrepreneur & 0 & 0 & 9 & 30 & 12 & 20 \\
\hline Civil servants & 0 & 0 & 9 & 30 & 7 & 11,7 \\
\hline Total & 10 & 100 & 30 & 100 & 60 & 100 \\
\hline
\end{tabular}

Table 2. Distribution of respondents cadres by the old cadre $(n=10)$

\begin{tabular}{clll}
\hline Old Cadre & $\mathbf{n}$ & $\boldsymbol{\%}$ \\
\hline $1-3$ years & 4 & 40 \\
\hline $4-6$ years & 2 & 20 \\
\hline
\end{tabular}




\begin{tabular}{ccl}
\hline $7-10$ years & 4 & 40 \\
\hline Total & 10 & 100 \\
\hline
\end{tabular}

Table 3. Competence of health cadres, Public Figures and The Family in the prevention, early detection and handling of emergencies pregnancy before and after the learning method of multi-level education

\begin{tabular}{llll}
\hline Competence & $\mathbf{x}$ & SD & Min-Max \\
\hline Competence of Health Cadres & & & \\
\hline Pre & 70 & 4,1 & $44,4-888$ \\
\hline Post & 93 & 4,3 & $88.8-93.3$ \\
\hline & & & \\
\hline Competence of Public Figures & & & $16.1-94.4$ \\
\hline Pre & 61.1 & 3.04 & $50-100$ \\
\hline Post & 80.5 & 3.65 & \\
\hline \multicolumn{1}{l}{ Competence of The Family } & & \\
\hline Pre & & & $22.2-88.8$ \\
\hline Post & 58 & 3.83 & $33.3-100$ \\
\hline & 78.8 & 4.25 &
\end{tabular}

Table 6. Effectiveness table of Katoga multi-level education learning methods

\begin{tabular}{lccc}
\hline Competence & $\mathbf{x}($ Pre $)$ & $\mathbf{x}$ (Post) & pValue \\
\hline Health Cadres & 70 & 93 & 0.003 \\
\hline Public Figures & 61.1 & 80.5 & 0.000 \\
\hline Family & 58.0 & 78.8 & 0.000 \\
\hline
\end{tabular}

The period of time to become a health cadre is $40 \%$ between $1-3$ years and $40 \%$ between 7 10 years. The competence of health cadres in the prevention, early detection and handling of emergency pregnancies before being given an average education of 70 and after an average multi-level education learning method 93. The competence of public figures in the prevention, early detection and handling of emergency

Analysis of the effectiveness of the Katoga multi-level education learning method on the competence of cadres, community leaders and families in preventing, detecting early and handling emergency pregnancy to reduce MMR

\section{DISCUSSIONS}

In the initial step education is given to health cadres, then health cadres provide education to community leaders and subsequently community leaders provide pregnancies before being given an average education of 61,1 and after an average multilevel education learning method 80,5. The competence of the families in the prevention, early detection and handling of emergency pregnancies before being given an average education of 58,0 and after an average multilevel education learning method 78,8.

/IMR shows that the multi-level learning method of Katoga education is effective in increasing the competence of cadres, community leaders and families in preventing, detecting early and managing emergency pregnancy to reduce MMR / IMR.

education to families. From the results of the study found an increase in competence regarding prevention, early detection and handling of pregnancy emergencies from health cadres with an average value of 70 to an average value of 93 . The increase indicates the competency education approach to 
learning methods that contain real case discussions, then discussed from risk factors, how to detect early and deal with emergencies so that cadres become competent in concluding the problem. Education with the method of discussing cases that often occur is intended to find more and more sides of the learning process as a basis for developing further learning. What is done is more a series of lesson study activities that are able to develop teacher competencies (in this case health cadres who are trained as health teachers in the community). Strategic alignment and evaluation results inform each other in a gradual transformation process (Ali, 2009). The results are also synergized with the findings of Tsui et al., 2012, which concluded that community collaboration and partnership is one innovative work community based on determinants of social health.

Increased competence of community leaders after being given a multi-level training on educational teaching methods by health cadres where the original value averaged 61.1 to an average of 80.5. This success cannot be separated from the role of competent health cadres in providing education and training because it is supported by the age of health cadres who are relatively young and mature in interacting with the community, which is 3437 years as much as $60 \%$. Age is classified as an adult age physically and psychologically to be able to influence others. In addition, it is also supported by the education of health cadres who are mostly $(60 \%)$ of secondary school. Age and education have an influence on knowledge (Robiyanto et al, 2018). The findings of this study are also in line with the opinion of Gamrin et al (2012) where the lack of the ability of public health educators is caused by the lack of knowledge, experience and skills of the instructor, so that the impact on health promotion program coverage has not reached national standards. The results of this study found that the competency value of health cadres before giving counseling to community leaders is also good namely an average score of 93 with a minimum value of
88 and a maximum value of 93.3. Besides being supported by their experience as health cadres, $40 \%$ have 7-10 year's experience as health cadres.

Competence family before being given a multi-level training of teaching methods of education by community leaders an average value of 58.0 and after being given the average training amounted to 78.8. Whereas the community leaders who provided the training previously had competencies with an average value of 80.5 . This finding synergies with the already reported by Astuti in 2018, in which health promotion and improving the knowledge of pregnant women can reduce the incidence of anemia, a good knowledge about the dangers of pregnancy cause maternal antenatal obedient. The success of the program in order to create a quality small family is very much determined by the active role of the family or community at various levels. The family plays a role in preventing maternal death, helping to create healthy conditions for childbirth and reducing the risk of pregnancy-related death for women (Hayuningsih, 2017).

An outcome of learning outcomes are quite effective at saving costs, time and effort, but the achievements of results can cover wide population. The results of this study are synergized with Ball's opinion in 2009 which explains that an educational approach such as multi-level education or chain involving other parties is effective in increasing diversity of information with a wider range. This learning method in accordance with the offered Noor, M. in 2011, where a variety of community empowerment strategies as the process develops, make independent, empowering, strengthening the bargaining position of the lower layers of society against the forces of suppression in all areas and sectors of life. This learning method in accordance with the offered Noor, M. in 2011, where a variety of community empowerment strategies as the process develops, independence, trade out, strengthening the bargaining position of the lower layers of society against the forces of 
suppression in all areas and sectors of life. The concept of empowerment is positioning society not only as an object of beneficiaries (beneficiaries) are dependent on the provision of outside parties such as the government, but rather in the position of the subject (agent or participant who acts) which act independently (rather than a means to escape from the responsibilities of government) to give health services. Community empowerment model health sector include the ability to identify and solve health problems (Sulaiman et al.,2012).

Early detection of high-risk pregnancy by the public relating to the classification or activity to get information about pregnant women who are detected as high-risk populations. It allows the public and health care workers to perform adequate maintenance and managed to reduce maternal and child mortality. Pregnant women with better personal autonomy will be able to detect risks and assess their pregnancy and can choose health care institutions (Sugiarti \& Mochny, 2012). Community empowerment efforts on an ongoing basis, as a public initiative not only government program capable of realizing success in achieving the objectives (Mardiyono, 2017). Also recently in 2019, Azinar \& Wahyuningsih reported the results of their research that community participation, especially health cadres, public figures, families correlated between their health education and their ability to detect pregnancy risks so that they would indirectly provide counseling to pregnant women who are experiencing risk.

\section{CONCLUSIONS}

Katoga's multi-level learning methods to prevent, detect early and deal with emergencies in emergency pregnancies are able to improve the competence of health cadres, public figures and families.

\section{Acknowledgment}

Acknowledgments The author extend to AIPNI / AINEC which has provided research funds "reseach award" as well as colleagues' faculty, students and the respondent.

\section{REFERENCES}

Acni, Nurul, K.P. dan P.K.P., 2013. Faktor Risiko Kematian Ibu. Jurnal Kesehatan Masyarakat Nasional 7,7.

Ali Mahmudi., 2009. Mengembangkan Kompetensi Guru Melalui Lesson Study.

Jurnal Forum Kependidikan, 28(2), 84-89.

Asmuji \& Indriyani Diyan, 2014. Buku Ajar Keperawatan Maternitas: Upaya Provontif dan Preventif dalam Menurunkan Angka Kematian Ibu dan Bayi. Yogyakarta: Ar-Ruzz Media.

Astuti, S. 2018. Skrening Kehamilan Sebagai Upaya Peningkatan Kesehatan Ibu Hamil Di Desa Cipacing Kecamatan Jatinangor Kabupaten Sumedang. Dharmakarya, 7(4).

Azinar, M., \& Wahyuningsih, A. S. 2019. Pos Keluarga Siaga Untuk Risk Mapping Dan Micro Counseling Kehamilan Risiko Tinggi Di Daerah Pedesaan Kabupaten Kendal. Rekayasa, 16(2), 245-258.

Ball, S. J. 2009. Privatising education, privatising education policy, privatising educational research: Network governance and the "competition state." Journal of Education Policy, 24(1), 83-99.

Gamrin, Thaha, Naiem. 2012. Kemampuan Penyuluh Kesehatan Masyarakat TerhadapCakupan Program Promosi Kesehatan di Kabupaten Maros. Fakultas Kesehatan Masyarakat Universitas Hassanudin Makassar (http://pasca.unhas.ac.id/jurnal/files/ae 250070fdddb10ff93e11c5d58b6481.pd f) Diakses pada tanggal 20 Agustus 2019

Hayuningsih, P. 2017. Peranan Keluarga Berencana Dalam Mencegah KematianIbu. 
Joint Committee on Reducing Maternal and Neonatal Mortality in Indonesia, 2013. Reducing maternal and neonatal mortality in Indonesia: saving lives, saving the future, The National AcademiesPress.

Macdorman, M.F., Declercq, E., Cabral, H., Morton, C., 2016. Recent Increases in the U.S. Maternal Mortality Rate: Disentangling Trends from Measurement Issues. Obstetrics and Gynecology 128,447-455.

Mardiyono. 2017. Pemberdayaan Keluarga Melalui Kampung KB Dalam Upaya Peningkatan Program KKBPK dan Terkait di Jawa Timur . Jurnal Keluarga Berencana, 2(1), 1-10

Noor, M. 2011. Pemberdayaan Masyarakat. Jurnal Ilmiah CIVIS, 1(2), 88. Robiyanto, Rosmimi, M., \& Untari, E. K. 2018. Analisis Pengaruh Tingkat Pengetahuan Masyarakat Terhadap Tindakan Swamedikasi Diare Akut di Kecamatan Pontianak Timur. Edukasi: Jurnal Pendidikan, 16(1), 135-145.

Sastrawinata S, Martaadisoebrata, Wirakusumah FF., 2010. Ilmu Kesehatan Reproduksi: Obstetri Patologi. Jakarta: EGC.

Sulaeman, E. S., Karsidi, R., Murti, B., Kartono, D. T., Waryana, W., \& Hartanto, R. (2012). Model Pemberdayaan Masyarakat Bidang Kesehatan, Studi Program Desa Siaga. Kesmas: National Public Health Journal, 7(4),186.
Sugiarti; Soedirham, O., \& Mochny, I. S. 2012. Upaya pemberdayaan ibu hamil untuk deteksi dini risiko tinggi kehamilan trimester satu. The Indonesian Journal of Public Health, 9(1), 27-36.

Sugiyono. 2015. Metode Penelitian Pendidikan (Pendekatan Kuantitatif, Kualitatif dan $R \& D)$. Penerbit CV. Alfabeta: Bandung.

Syafiq, A., Budiantoro S., 2013. Angka Kematian Ibu (AKI). kesehatan reproduksi, 1-4.

Tsui, E., Bylander, K., Cho, M., Maybank, A., \& Freudenberg, N. (2012). Engaging youth in food activism in New York city: Lessons learned from a youth organization, health department, and university partnership. Journal of Urban Health, 89(5), 809-827.

Turniani dan Roosihermiatie, B.L., 2007. Kebijakan Dalam Upaya Menurunkan Angka Kematian Ibu dan Angka Kematian Bayi Di 5 Kabupaten/Kota Provinsi Kalimantan Selatan. Buletin Penelitian Sistem Kesehatan 10, 109- 115.

Unicef, 2012. Ringkasan Kajian Kesehatan Ibu dan Anak. UNICEF Indonesia 12. Weeks, A., 2007. Maternal mortality: It's time to get political. BJOG: An International Journal of Obstetrics and Gynaecology 114, 125-126. 